\title{
Construction of Outside College Practice Bases for 3P High-level Applied Talents Training
}

\author{
Jili Tao ${ }^{1, a}$, Weiming Cai ${ }^{1, b,{ }^{*}}$, Yuting Zhuang ${ }^{1, c}$ \\ Shengli Fan ${ }^{1, d}$, Lingong $\mathrm{Li}^{1, \mathrm{e}}$ and Jun Qiu ${ }^{1, f}$ \\ ${ }^{1}$ Ningbo Institute of Technology, Zhejiang University, Ningbo, 315100, China

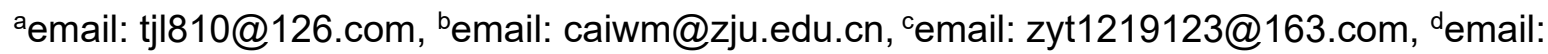 \\ victorfs।@nit.net.cn, eemail: nitllg@qq.com, femail: qiujunnb@zju.edu.cn.
}

${ }^{*}$ Corresponding author

Keywords: School-enterprise cooperation, engineering education, talent training

\begin{abstract}
The participation of industry enterprises is critical to develop the students' practical capability, professional quality and industry cognition capability. Based on the characteristics of Ningbo industry, a new sustainable talent-developing mode of school-enterprise deep integration is constructed from five aspects, which contains talent-training objectives, specialty curriculum system, training ways, evaluation methods and guarantee conditions. The construction of outside college practice bases aims to achieve an all-win situation for enterprises, universities and students.
\end{abstract}

\section{Introduction}

As is proposed in the national engineering education professional certification standard, schools should cooperate with enterprises to build a practice and training base, and provide students with a platform to participate in engineering practice in the teaching process. While the development of enterprises requires high-quality reserve talents, transformation of scientific research achievements and training of enterprise employees. However, the enterprises usually cannot obtain positive income when accepting students' factory practice; only a small part of students participating in industry-university cooperative education returned to the enterprise, and the final income of cooperative education was quite small [1]. At the same time, the existing school-enterprise cooperation faces the problem of narrow cooperation, single form, the lack of long-term cooperation foundation and not covering all processes of talent training [2]. To overcome these problems, North China Electric Power University explored the demand of industry enterprises, implemented the integration of production and education, and built a practice-oriented mode of school-enterprise cooperation talent training [3]. Liu et al utilized the statistics of 11 universities and manufacturing enterprises cooperation patents in Zhejiang Province, they concluded that the complement resources, the compatibility between school-enterprise strategy and culture, mutual confidence and long-term development were the base of cooperation innovation between universities and enterprises [4]. Lin et al detailed the implementation plan of high-level, comprehensive and applied talent training in China from the perspective of state, government, universities and enterprises [5].Therefore, it is necessary to attract enterprises to actively participate in specialty teaching activities and provide engineering practice conditions.

\section{Target of school-enterprise cooperation}

The Relying on the base of intelligent sensing and wireless communication, Electronic Information Engineering provided the talent support and technical services for Ningbo and its surrounding electronic information industry. With the support of the government and schools, the cooperation among enterprises, teachers and students are deepen, and the information interaction, resource sharing, mutual benefit and multilateral win-win between schools and markets are realized. The 
school-enterprise cooperation professional talent training program aimed at practical ability, professional quality and industry prospect is shown in Fig. 1.

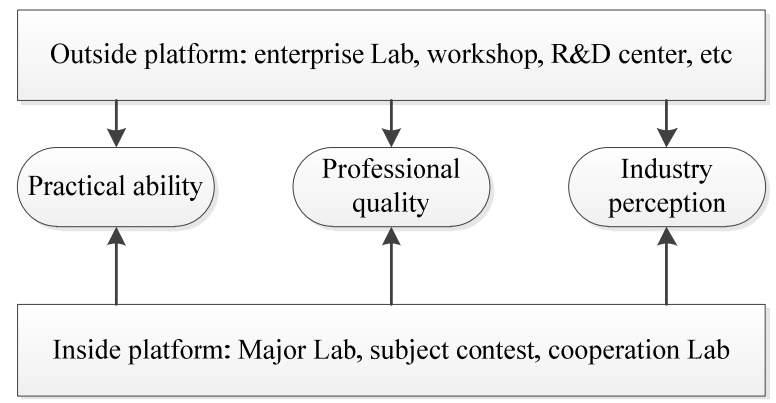

Fig.1. 3P professional talent training for school-enterprise cooperation

\section{Implementation scheme of school-enterprise cooperation}

\subsection{School-enterprise cooperation platform expansion}

Generally, growth-type enterprises are more motivated to participate in talent training. We establishes a school-enterprise cooperation platform through various ways, such as government agency platforms, school research offices and teacher research cooperation. The demand of school-enterprise cooperation in enterprises is helpful to establish the internship training bases and provide corresponding training personnel. Some cooperative enterprises are shown in Table 1.

Table 1. Some representative cooperative enterprises

\begin{tabular}{|c|c|}
\hline Company & Cooperation mode(No. of students) \\
\hline Tianan Intelligent Technology Co., Ltd. & Internship training(20) \\
\hline Ningbo Keli Sensor Co., Ltd. & Cognitive practice(100) \\
\hline Ningbo Dongfang Cable Co., Ltd. & Internship training(20) \\
\hline Ningbo Hongxun Technology Co., Ltd. & Internship training(20) \\
\hline Ningbo Zhongce Electronics Co., Ltd. & Cognitive practice(100) \\
\hline
\end{tabular}

\subsection{Institutional guarantee to promote integration of production and education}

In order to realize the deep integration of school-enterprise cooperation, the professional training plan is conducive to the demand enterprise talent, some enterprise experts are invited to revise the training program and satisfy the enterprise's demand for talents. Some enterprise experts revising the professional training plan are shown in Table 2.

Table 2. Corporate experts for professional training plan revision

\begin{tabular}{|c|c|}
\hline Company & Position \\
\hline Ningbo Mobile Co., Ltd. & company deputy general manager \\
\hline Ningbo New Energy Technology Co., Ltd. & Professor-level senior engineer \\
\hline Haitian Group Co., Ltd. & Senior engineer \\
\hline China Railway East China Investment Development Co., Ltd. & Senior engineer / Party secretary \\
\hline Wolong Electric Group Co., Ltd. & Professor-level senior engineer \\
\hline Ningbo Tianrui Medical Devices Co., Ltd. & Professor-level senior engineer \\
\hline
\end{tabular}




\subsection{In and outside college cooperation promoting students' 3P ability}

\subsubsection{Four-year continuous practice training in school to promote students' practical ability}

After entering the school, the students will be guided to participate in the "Amateur Radio" and "Electronic System Design" clubs to understand the professional characteristics and cultivate professional interests. Through the course experiments metalworking internship, electronic technology internship, professional comprehensive practice, discipline competition, graduation design, student research plan, participation in teacher's science research and other practical works, students continuously receive professional practice and gradually improve their application practice ability. Each student will be assigned a tutor to guide the practice works.

3.3.2 Cooperation in and outside school to cultivate students' professionalism

The cultivation of professional literacy begins with the course of professional introduction for freshman. Part of the training arrangements of school-enterprise cooperation with a company is shown in Table 3.

Table 3. Example of the training content of school-enterprise cooperation

\begin{tabular}{|c|c|}
\hline Date & Internship content plan \\
\hline \multirow[b]{2}{*}{7.09} & $\begin{array}{l}\text { Opening ceremony, training objectives and plan explanation. } \\
\text { Power industry cognition. }\end{array}$ \\
\hline & $\begin{array}{l}\text { Case study of the combination of electronics, electrical principles, circuit concepts and industry } \\
\text { applications. } \\
\text { Practical courses: design circuits, wiring, assembly given components. }\end{array}$ \\
\hline \multirow{2}{*}{7.10} & Power, energy, new energy concepts, principles and industry application analysis. \\
\hline & Project Discussion: Discussion on Energy Conversion, Distribution, Storage and Utilization. \\
\hline $7.12-13$ & Course Design \\
\hline \multirow{2}{*}{7.16} & Company introduction, interact with the students, introduce the corporate culture. \\
\hline & Typical case analysis of quality system, routine product testing and after-sales service. \\
\hline \multirow[b]{2}{*}{7.17} & Safety production education; 6S management training. \\
\hline & $\begin{array}{l}\text { Practical experience: workshop practice, full participation in product production process, } \\
\text { commissioning, inspection of the whole process experience. }\end{array}$ \\
\hline \multirow{3}{*}{7.18} & Company leading product introduction, product site view and explanation. \\
\hline & Design related software application introduction, software field operation simulation. \\
\hline & Design process and key points; project discussion: how to design a good product. \\
\hline \multirow{2}{*}{7.19} & $\begin{array}{l}\text { Product Technology Practice Course: Product Development Lecture. } \\
\text { Technical Knowledge Management Lecture. }\end{array}$ \\
\hline & $\begin{array}{l}\text { Product and market knowledge lectures, market orientation, product marketing, customer relations, } \\
\text { business etiquette, etc. }\end{array}$ \\
\hline 7.20 & Software field operation training \\
\hline \multirow[t]{2}{*}{7.23} & $\begin{array}{l}\text { Measurement and control technology, measurement and control instrumentation, industrial } \\
\text { automation, SCADA introduction, automation case. }\end{array}$ \\
\hline & Project Discussion: Design of power system automation system. \\
\hline 7.25 & Marketing project (student group work report). \\
\hline $7.26-29$ & Course Design at school \\
\hline \multirow{2}{*}{7.30} & $\begin{array}{l}\text { Intelligent technology, Internet of Things, smart grid technology introduction, product case } \\
\text { analysis. }\end{array}$ \\
\hline & $\begin{array}{l}\text { Thematic explanation: detailed explanation of smart grid demonstration project design and } \\
\text { curriculum design. }\end{array}$ \\
\hline $7.31-8.1$ & Course Design at school \\
\hline 8.2 & Course defense, internship summary, graduation ceremony \\
\hline
\end{tabular}




\subsubsection{Building complex engineering problem to develop students' industry prospect}

A large number of Ningbo manufacturing companies require intelligent sensing technologies, such as machine vision, to intelligently upgrade existing production lines, save increasing labor costs, improve the production efficiency and promote their market competitiveness. The embedded machine vision 3D scanning measurement system is used as the foothold of complex engineering problems, which is obtained from the operational objects in industrial production. The whole process is completed from the analysis of visual 3D measurement principles to system structure design, production design of embedded circuit systems, and the realization of image processing software, the collaboration of mechanical motion mechanisms and simulation of the visual inspection process in practical industrial applications.

\section{Conclusions}

A kind of new internship training base is set up combining both in the enterprise and the school. The college and the enterprise provide a number of tutors participating in student training and cooperating in product research and development. Both of them participate in the development of training teaching plan and course content arrangement, which is beneficial to the successful development of the school-enterprise training session. For enterprises, with the integration of training and business management, students participating in training and performing well become the reserve talents of the enterprise; for students, they are truly involved in the actual product development; for teachers, they establish long-term cooperative relationships with the enterprise and can fully serve enterprises and develop science research. In the various aspects of school-enterprise cooperation, the "practical ability", "professional quality" and "industry prospect ability" are infiltrated to achieve a win-win situation. However, at present, the cooperative enterprises are still uneven, the form of cooperation is still single, narrow and not covering all aspects of the personnel training.

\section{Acknowledgment}

This research was financially supported by Ningbo Education Planning Foundation under Grant (2017YZD008) \& the key project of NIT on technology teaching research and reform under Grant (NITJG-201914).

\section{References}

[1] H. Hu, J. Zhu. Analysis on the Dilemma of Enterprise Collective Action in Industry-University Cooperation and Cultivation of Talents. Higher Education of Engineering, vol. 1, pp. 51-59, 2011.

[2] D. Cao. From "School-enterprise Cooperation" to "Integration of Production and Education"-Confusion and Thinking of Application-oriented Undergraduate Universities to Promote Deep Integration of Production and Education. Tianzhong Journal, vol. 30, pp. 133-138, 2015.

[3] C. Liu, Y. Bai, K. Yang. Constructing a talent-training model for "special-oriented, school-enterprise cooperation" industry-specific universities. China University Teaching, vol. 1, pp. 36-41, 2016.

[4] K. Liu, X. Yong. Research on the Matching Law and Countermeasure of University and Enterprise Cooperative Innovation-Taking the School-enterprise Cooperation Innovation in Zhejiang Province as an Example. Higher Education Research, vol. 4, pp. 50-56, 2014.

[5] J. Lin. School-enterprise cooperation in the development of excellent engineers. Higher Education Research, vol. 3, pp. 7-23, 2012. 